GRASAS Y ACEITES 66 (3)

July-September 2015, e087

ISSN-L: 0017-3495

doi: http://dx.doi.org/10.3989/gya.1313143

\title{
Rheological properties and physical stability of ecological emulsions stabilized by a surfactant derived from cocoa oil and high pressure homogenization
}

\author{
L.A. Trujillo-Cayado, A. Natera, M.C. García, J. Muñoz and M.C. Alfaro ${ }^{\bowtie}$ \\ Reología Aplicada. Tecnología de Coloides. Departamento de Ingeniería Química. Facultad de Química. \\ Universidad de Sevilla c/P. García González, 1, E41012, Sevilla, Spain \\ Corresponding author: alfaro@us.es
}

Submitted: 22 December 2014; Accepted: 10 February 2015

SUMMARY: The goal of this work was to investigate the influence of the emulsification method on the rheological properties, droplet size distribution and physical stability of $\mathrm{O} / \mathrm{W}$ green emulsions formulated with an eco-friendly surfactant derived from cocoa oil. The methodology used can be applied to other emulsions. Polyoxyethylene glycerol esters are non-ionic surfactants obtained from a renewable source which fulfill the environmental and toxicological requirements to be used as eco-friendly emulsifying agents. In the same way, N,NDimethyloctanamide and $\alpha$-Pinene (solvents used as oil phase) could be considered green solvents. Emulsions with submicron mean diameters and slight shear thinning behavior were obtained regardless of the homogenizer, pressure or number of passes used. All emulsions exhibited destabilization by creaming and a further coalescence process which was applied to the coarse emulsion prepared with a rotor-stator homogenizer. The emulsion obtained with high pressure at 15000 psi and 1-pass was the most stable.

KEYWORDS: Eco-friendly surfactant; Ecological emulsion; High pressure homogenization by microchannels; Multiple light scattering; Rheology

RESUMEN: Propiedades reológicas y estabilidad física de emulsiones ecológicas estabilizadas por un tensioactivo derivado del aceite de coco y homogeneización de alta presión. El objetivo de este trabajo fue estudiar la influencia del método de emulsificación sobre las propiedades reológicas, la distribución de tamaños de gota y la estabilidad física de emulsiones verdes $\mathrm{O} / \mathrm{W}$ formuladas con un tensioactivo derivado del aceite de coco respetuoso con el medioambiente. La metodología empleada puede ser aplicada a cualquier otro tipo de emulsiones. Los ésteres polietoxilados de glicerina son tensioactivos no iónicos obtenidos de fuentes renovables que cumplen requisitos medioambientales y toxicológicos para ser usados como agentes emulsionantes ecológicos. Del mismo modo, la N,N-dimetil octanamida y el $\alpha$-Pineno (disolventes usados como fase oleosa) pueden ser considerados como disolventes verdes. Se han obtenido emulsiones con diámetros medio submicrónicos y comportamiento ligeramente pseudoplástico independientemente del equipo, la presión o el número de pasadas empleados. Todas las emulsiones presentaron desestabilización por cremado y un proceso posterior de coalescencia que fue completado por la pre-emulsión preparada con un homogeneizador rotor estator. La emulsión obtenida con el homogeneizador de alta presión a 15000 psi y 1-pasada fue la más estable.

PALABRAS CLAVE: Emulsión ecológica; Homogeneización de alta presión por microcanales; Múltiple light scattering; Reología; Tensioactivo ecológico

Citation/Cómo citar este artículo: Trujillo-Cayado LA, Natera A, García MC, Muñoz J, Alfaro MC. 2015. Rheological properties and physical stability of ecological emulsions stabilized by a surfactant derived from cocoa oil and high pressure homogenization. Grasas Aceites 66 (3): e087. doi: http://dx.doi.org/10.3989/gya.1313143.

Copyright: (C) 2015 CSIC. This is an open-access article distributed under the terms of the Creative Commons Attribution-Non Commercial (by-nc) Spain 3.0 Licence. 


\section{INTRODUCTION}

Emulsions are dispersions of two or more immiscible liquid phases, usually water and oil. If the disperse phase is a lipophilic liquid and the continuous phase is a hydrophilic liquid, then it is an oil-inwater $(\mathrm{O} / \mathrm{W})$ emulsion.

Emulsions often contain a surface active agent which has two main functions: a) to decrease the interfacial tension between phases enabling easier formation of the emulsion, and b) to stabilize the dispersed-phase against coalescence once it is formed (Muñoz et al., 2007). Surfactants obtained directly from renewable natural materials are gaining more and more attention since they are more eco-friendly than traditional ones (Gómez, 2009; Ruiz-Márquez et al., 2010). Polyoxyethylene glycerol esters derived from cocoa oil are non-ionic surfactants obtained from a renewable source which fulfill the environmental and toxicological requirements to be used as emulsifying agents (Bermejo et al., 2002). These surfactants are completely innocuous for human skin and hair, and their properties are adequate for designing eco-friendly products (Castán and González, 2003; Lutz, 2006; Yu et al., 2008; Denolle et al., 2011). The safety data sheet provided by the supplier reports a value for oral toxicity (LD50) higher than $5000 \mathrm{mg} \cdot \mathrm{kg}^{-1}$ of animals in tests carried out with rats. It is interesting to note that this value would be $3000 \mathrm{mg} \cdot \mathrm{kg}^{-1}$ for salt (Hollinger, 2005). In addition, the interfacial properties at the air/water and $\alpha$-pinene/water interface of these surfactants, namely equilibrium adsorption, dynamic surface tension and interfacial rheology, have been recently reported (Trujillo-Cayado et al., 2014a; TrujilloCayado et al., 2014b).

Regarding the oil phase, it is also important to highlight the trend towards using eco-friendly solvents such as fatty acid dimethylamides and $\alpha$-Pinene. $\alpha$-Pinene is a terpenic solvent that can be obtained from the essential oils of juniper, rosemary and eucalyptus (García et al., 2014). This renewable biosolvent is completely miscible with oils and insoluble in water (Bertouche et al., 2013). Fatty acid dimethylamides are among the green solvents found in agrochemical applications (Höfer and Bigorra, 2007).

In order to produce emulsions, the disperse phase must be distributed in finely divided form throughout the continuous phase. Droplet size is an important property because it determines the shelf life stability, consistency and rheological properties of the emulsion (Israelachvili, 1994). In many cases, the aim of emulsification is to produce droplets which are as fine as possible $(\mathrm{d}<1 \mu \mathrm{m})$. Fine emulsions can be produced in many different ways. The most frequent processes for emulsification are the rotorstator systems and the high pressure homogenizers (Schultz et al., 2004). High pressure homogenization based on micro-channel technology (Microfluidics) is the methodology of choice if fluid-like emulsions with submicron mean diameters and narrow droplet size distributions (DSD) are the target, since they can reach extremely high shear rates (Vladisavljević et al., 2004). Microfluidization processing implies that a coarse emulsion is passed through an interaction chamber using a high pressure pumping device (Jafari et al., 2007a). The interaction chamber consists of two flow channels which are designed to make two coarse emulsion streams collide with each other at a high velocity, thus creating a very high shearing action that provides an exceptionally fine emulsion (Salvia-Trujillo et al., 2014).

The main objective of this work was to study the influence of the emulsification method on the rheological properties, droplet size distribution and physical stability of green $\mathrm{O} / \mathrm{W}$ emulsions formulated with an eco-friendly surfactant derived from cocoa oil. The methodology resulting from this work can be applied to any kind of emulsion.

\section{MATERIALS AND METHODS}

\subsection{Materials}

$\mathrm{N}, \mathrm{N}$-dimethyloctanamide (Agnique AMD- ${ }^{\mathrm{TM}}$ ) and $\alpha$-Pinene, supplied by BASF and Sigma-Aldrich respectively, were used as the oil phase to prepare the emulsions studied. The AMD- $8^{\mathrm{TM}} / \alpha$-Pinene mass ratio was kept constant at 75/25 (Trujillo-Cayado et al., 2013).

A polyoxyethylene glycerol ester derived from cocoa oil, namely Levenol C-201 ${ }^{\mathrm{TM}}$ (Glycereth-17 cocoate, HLB=13), received as a gift from KAO, was used as the emulsifier. Deionized water was used for the preparation of all emulsions.

\subsection{Methods}

\subsubsection{Emulsification process}

Oil-in-water emulsions were produced by homogenizing $30 \mathrm{wt} \%$ oil (a mixture of oils) with a $70 \mathrm{wt} \%$ aqueous phase containing a $3 \mathrm{wt} \%$ surfactant.

Firstly, coarse emulsions were prepared with an Ultraturrax T-50/G45F rotor-stator device by applying a rotational speed of $4000 \mathrm{rpm}$ for $120 \mathrm{~s}$ at room temperature. Levenol C-201 ${ }^{\mathrm{TM}}$ was dispersed in the corresponding amount of water. Then the oils were mixed. Afterwards, the oil phase was added slowly to the aqueous phase while the system was agitated using the aforementioned homogenizer.

Next, the coarse emulsions were immediately passed once or twice through the high pressure microchannel technology homogenizer (Microfluidizer M110P, Microfluidics, Massachusetts, USA). Five homogenizing pressures were used: 5000, 10000, $15000,20000$ and 25000 psi (34.47 to $172.37 \mathrm{MPa})$. 
The homogenizing chamber was cooled using a cooling jacket containing water at $20^{\circ} \mathrm{C}$ in order to minimize the temperature rise.

The nomenclature used to denote the emulsions is as follows: $\mathrm{X} / \mathrm{Y}$ stands for $30 \mathrm{wt} \%$ oil emulsions containing $3 \mathrm{wt} \%$ Levenol C- $201^{\mathrm{TM}}$ which have been prepared at $\mathrm{X}$ psi of pressure and $\mathrm{Y}$ number of passes through the high pressure homogenizer.

\subsubsection{Droplet size distribution (DSD)}

Droplet size distributions of emulsions aged for $1,3,10$ and 30 days were measured using a static light scattering instrument (Mastersizer X; Malvern Instruments, UK) after samples had been diluted with water. The refraction and absorption indexes used for the continuous medium were 0.1 and 1 , respectively, whereas the refraction index for the dispersed phase was 1.53 . The full size distribution was obtained using a poly-disperse analysis.

The mean droplet diameters were expressed as Sauter diameter $\left(\mathrm{D}_{3,2}\right)$ and volume mean diameter $\left(\mathrm{D}_{4,3}\right)$ :

$$
\begin{aligned}
& D_{3,2}=\sum_{i=1}^{N} n_{i} d_{i}^{3} / \sum_{i=1}^{N} n_{i} d_{i}^{2} \\
& D_{4,3}=\sum_{i=1}^{N} n_{i} d_{i}^{4} / \sum_{i=1}^{N} n_{i} d_{i}^{3}
\end{aligned}
$$

where $d_{i}$ is the droplet diameter, $\mathrm{N}$ is the total number of droplets and $n_{i}$ is the number of droplets having a diameter $\mathrm{d}_{\mathrm{i}}$.

The "span" was used to determine the distribution width of droplet sizes, which was calculated as follows:

$$
\operatorname{Span}=\frac{D(v, 0.9)-D(v, 0.1)}{D(v, 0.5)}
$$

where $\mathrm{D}[\mathrm{v}, 0.9]$ and $\mathrm{D}[\mathrm{v}, 0.1]$ stand for the 90 th and 10th percentiles and $\mathrm{D}[\mathrm{v}, 0.5]$ for the median.

Determinations were conducted in triplicate.

\subsubsection{Rheological measurements}

Dynamic viscosities were calculated from flow curves determined at $20 \pm 0.1{ }^{\circ} \mathrm{C}$ with a controlled stress rheometer (Haake Mars, Thermo-Scientific, Germany), connected to a C5P Phoenix circulator (Thermo-Scientific, Germany). Viscous flow tests were carried out within a stress range of $0.05-2 \mathrm{~Pa}$, using a sandblasted Z20 coaxial cylinder geometry $(\mathrm{Ri}=1 \mathrm{~cm}, \mathrm{Re} / \mathrm{Ri}=1.085)$. This special surface sensor system was used to avoid slip effects.
The samples were loaded into the rheometer measurement cell and allowed to equilibrate for 600 s before beginning the test to allow for stress relaxation.

The results represent the mean of at least two measurements taken on emulsions aged for 1, 3, 13, 21 and 40 days.

\subsubsection{Multiple light scattering}

The destabilization of emulsions was monitored by multiple light scattering using an optical scanning instrument (Turbiscan Lab Expert). This instrument measured the back scattering of monochromatic light $(\lambda=880 \mathrm{~nm})$ from an emulsion as a function of its height. Emulsions were placed into cylindrical glass tubes and stored at room temperature. The back scattering of light from emulsions was then measured with height at different times. The results may be presented either as a backscattering percentage $(\% \mathrm{BS})$ or in reference mode (deltabackscattering), i.e. by subtracting the first scan from all the subsequent scans made.

\section{RESULTS AND DISCUSSION}

\subsection{Droplet size distribution}

Figure 1 shows the droplet size distributions (DSDs) of the emulsions aged for $24 \mathrm{~h}$ as a function of the different emulsification processes.

The emulsions prepared with a high pressure homogenizer showed two populations of droplets regardless of the pressure or the number of passes. The main peak is below 1 micron and the second population is centered at about three microns. The occurrence of the second population of droplets is due to a re-coalescence phenomenon of new

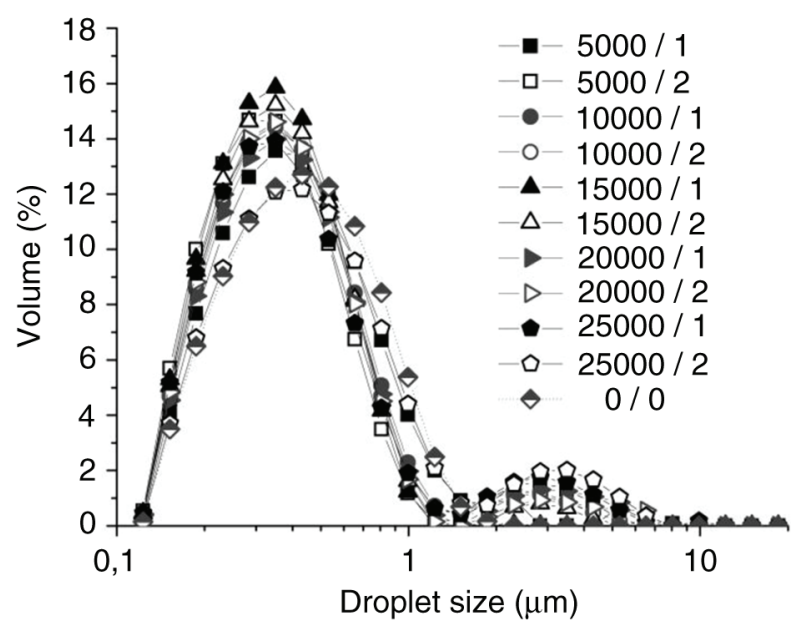

Figure 1. Droplet size distributions for emulsions aged 24 hours as a function of the emulsification variables. 
droplets as a consequence of some over-processing (Jafari et al., 2007b). During homogenization, the residence time of the surfactant in the chamber of the homogenizer might not be sufficient to allow for its adsorption on the droplet surfaces before droplet-droplet collisions occurred. The high turbulent intensity that is acting on the sample could lead to a higher collision rate between drops, thus resulting in a higher coalescence rate (Floury et al., 2004). This means that the extremely high energy per unit volume provided by the high pressure homogenizer during the emulsification process partially breaks the $\mathrm{O} / \mathrm{W}$ interface formed by glycereth-17 cocoate surfactant, inducing a re-coalescence phenomenon. This is consistent with the fact that the appearance of this second peak occurred only for emulsions processed with the high pressure homogenizer. The emulsions processed with the Ultraturrax T-50 (coarse emulsion) showed a mono-modal DSD. The mean diameters and span are listed in Table 1 as a function of both the emulsification method and the processing variables. They reveal that the Microfluidizer M110P yielded emulsions with slightly lower mean diameters than the emulsion obtained with the Ultraturrax T50. Also shown is how they were not significantly affected by the homogenization pressure and that two passes through the high pressure homogenizer resulted in worse results, i.e. greater $\mathrm{D}_{3,2}, \mathrm{D}_{4,3}$ and span values. This last result may be due to a higher incidence of the re-coalescence phenomenon mentioned above. Interestingly, both devices (a rotor-stator and a high pressure homogenizer based on micro-channel technology) provided emulsions with similar submicron sizes. These results may be interpreted by taking into account the nature of both solvents. AMD- $8^{\mathrm{TM}}$ is a slightly

TABLE 1. Sauter diameter $\left(\mathrm{D}_{3,2}\right)$, volume mean diameter $\left(\mathrm{D}_{43}\right)$ and span of all studied emulsions aged for $24 \mathrm{~h}$ as a function of the emulsification method

\begin{tabular}{lcccc}
\hline Pressure (psi) & Passes & $\mathbf{D}_{3,2}(\mathbf{n m})^{\mathbf{a}}$ & $\mathbf{D}_{\mathbf{4}, \mathbf{3}}(\mathbf{n m})^{\mathbf{b}}$ & $\mathbf{S p a n}^{\mathbf{c}}$ \\
\hline Coarse emulsion & & 360 & 410 & 1.65 \\
5000 & 1 & 320 & 480 & 1.77 \\
& 2 & 340 & 500 & 1.52 \\
10000 & 1 & 300 & 440 & 1.60 \\
& 2 & 330 & 470 & 1.44 \\
15000 & 1 & 310 & 520 & 1.52 \\
& 2 & 340 & 540 & 1.66 \\
20000 & 1 & 280 & 400 & 1.41 \\
& 2 & 290 & 420 & 1.45 \\
25000 & 1 & 290 & 430 & 1.41 \\
& 2 & 350 & 680 & 1.71 \\
\hline
\end{tabular}

${ }^{a}$ Standard deviation of the mean (three replicates) $\mathrm{D}_{3,2}<5 \%$. ${ }^{\mathrm{b}} \mathrm{S}$ tandard deviation of the mean (three replicates) $\mathrm{D}_{4,3}<8 \%$. ${ }^{\mathrm{c}}$ Standard deviation of the mean (three replicates)span $<5 \%$. polar solvent and partially soluble in water. This partial solubility is a disadvantage for the development of oil-in-water emulsions because it may lead to a destabilization process by Ostwald ripening (Tadros, 2009). Conversely, $\alpha$-Pinene is a strongly non-polar solvent with a high interfacial tension $(\gamma=35.5 \pm 0.9 \mathrm{mN} / \mathrm{m})$. This may be a disadvantage during the emulsification process since lower interfacial tension results in a higher ability to break into droplets (Pérez-Mosqueda et al., 2014). Thus, by using these solvents alone we obtain emulsions with droplet sizes above $1 \mu \mathrm{m}$. However, the use of a mixture of these solvents allows us to prepare very small size emulsions with low energy. According to Santos et al. (2014) an increase in the AMD-10 $10^{\mathrm{TM}}$ content of an AMD-10/D-Limonene mixture caused a progressive decrease in the interfacial tension. It should be noted that the addition of just $1 \mathrm{wt} \%$ of AMD- $10^{\mathrm{TM}}$ to D-Limonene reduced interfacial tension by $33 \%$. This could be due to the fact that AMD $-10^{\mathrm{TM}}$ was able to migrate to the interface. There, both solvents were distributed according to
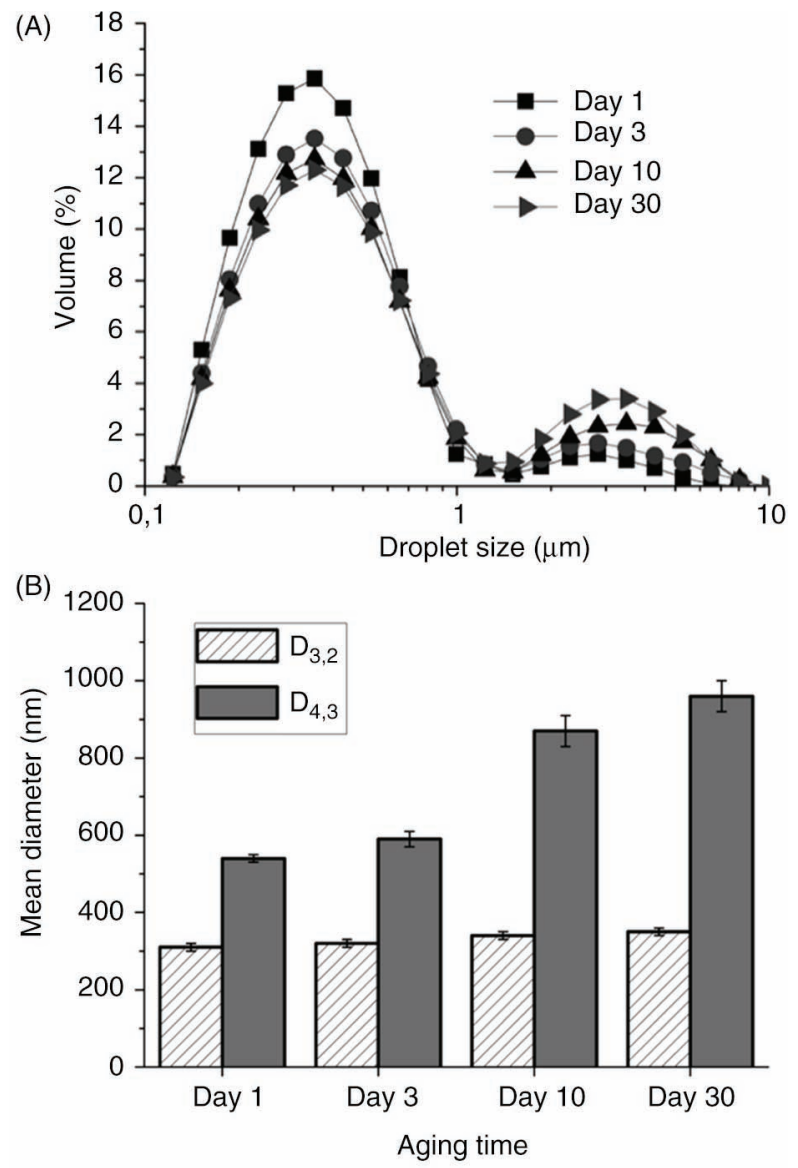

FIGURE 2. (A) Droplet size distributions and (B) Sauter mean diameter and volume mean diameter for the emulsion prepared with Microfluidizer M110P at $15000 \mathrm{psi}$ and 1 pass as a function of aging time. 
a concentration gradient which could be similar to a "core-shell" model (Lee and Lim, 2003) where the AMD- $10^{\mathrm{TM}}$ would tend to stay nearer the interface and D-Limonene in the core of droplets. This distribution makes it easier to create a higher interfacial area by applying the same amount of energy during the emulsification process. Taking into account the similarities between the AMD-10 ${ }^{\mathrm{TM}} / \mathrm{D}$-Limonene system and the AMD- $8^{\mathrm{TM}} / \alpha$-Pinene mixture, a similar situation may be taking place in these emulsions.

The evolution of both the droplet size distribution and the mean diameters with aging time allow for the detection of destabilization phenomena such as the coalescence or Ostwald ripening. A flocculation process cannot be considered since the flocks are disrupted under the action of stirring and pumping during a laser diffraction measurement. By way of example, Figures $2 \mathrm{a}$ and $2 \mathrm{~b}$ show the evolution of DSD and the mean diameters of the emulsion prepared at 15000 psi with 1 pass. All emulsions showed an increase in the $\mathrm{D}_{4,3}$ with aging time. However, substantial changes in $\mathrm{D}_{3,2}$ were not observed. Furthermore, both an increase in the second peak and a decrease in the population with smaller size were detected. This usually points to the occurrence of a destabilization process by coalescence instead of an Ostwald ripening phenomenon. For Ostwald ripening the particle size distribution should be shifted towards larger sizes without changing its shape, whereas with coalescence a bi-modal distribution is usually observed (McClements, 2007). If we compare the coarse emulsion with the emulsion obtained at high pressure, the worst behavior in terms of destabilization by coalescence was shown by the coarse emulsion.

\subsection{Rheological measurements}

All the emulsions exhibited shear-thinning behavior, which fitted the power-law equation $\left(\mathrm{R}^{2}>0.999\right)$ :

$$
\tau=k \cdot(\dot{\gamma})^{n}
$$

where $\tau$ is the shear stress, $k$ is the consistency index, $\dot{\gamma}$ is the shear rate and $n$ is the power law index. The consistency index has $\mathrm{Pa} \cdot \mathrm{s}^{\mathrm{n}}$ units, which depend on the power law index values. This prevents a direct comparison of this parameter for samples with different values of the power law index. To avoid this, we use a modified power law equation:

$$
\tau=\tau_{1} \cdot\left(\frac{\dot{\gamma}}{1 s^{-1}}\right)^{n}
$$

where $\tau_{1}$ is the shear stress value at $1 \mathrm{~s}^{-1}$. For shear thinning materials, $0<\mathrm{n}<1$. A solid material would show $\mathrm{n}=0$, while a Newtonian liquid would show $\mathrm{n}=1$.
TABLE 2. Flow curve fitting parameters for the power law model for the studied emulsions as a function of emulsification method. Aging time of $24 \mathrm{~h}$

\begin{tabular}{lcccc}
\hline Pressure (psi) & Passes & $\tau_{\mathbf{1}}(\mathbf{P a})^{\mathbf{a}}$ & $\mathbf{n}^{\mathbf{b}}$ & $\eta_{\mathbf{2 P a}}(\mathbf{m P a} \cdot \mathbf{s})^{\mathbf{c}}$ \\
\hline Coarse emulsion & & 0.0073 & 0.99 & 6.53 \\
5000 & 1 & 0.0080 & 0.97 & 6.86 \\
\multirow{2}{*}{10000} & 2 & 0.0082 & 0.96 & 6.77 \\
& 1 & 0.0090 & 0.95 & 6.69 \\
\multirow{2}{*}{5000} & 2 & 0.0092 & 0.95 & 6.91 \\
& 1 & 0.0090 & 0.97 & 6.85 \\
20000 & 2 & 0.0080 & 0.95 & 6.70 \\
25000 & 1 & 0.0097 & 0.95 & 6.67 \\
& 2 & 0.0098 & 0.93 & 7.22 \\
& 1 & 0.0092 & 0.95 & 7.52 \\
& 2 & 0.0099 & 0.94 & 6.93 \\
\hline
\end{tabular}

${ }^{\text {a }}$ Standard deviation of the mean (three replicates) $\tau_{1}<10 \%$.

${ }^{\mathrm{b}}$ Standard deviation of the mean (three replicates) $\mathrm{n}<10 \%$.

${ }^{\mathrm{c}} \mathrm{Standard}$ deviation of the mean (three replicates) $\eta_{2 \mathrm{~Pa}}<10 \%$.

Table 2 shows the values of fitting parameters for the emulsions aged for 24 hours as a function of processing variables. Furthermore, the apparent viscosity at a constant stress of $2 \mathrm{~Pa}\left(\eta_{2 \mathrm{~Pa}}\right)$ is exhibited, which is calculated as follows:

$C I=\frac{H_{S}}{H_{E}} \cdot 100$

All emulsions showed almost Newtonian behavior with a similar flow index, although the emulsion prepared with the Ultra Turrax T50 is closest to this behavior. Two passes through the Microfluidizer M110P gave a lower flow index regardless of the pressure applied. The fluid-like behavior of these emulsions was supported by their low apparent viscosity values ( $\eta_{2 \mathrm{~Pa}}$ ranged from 6.53 to $7.52 \mathrm{mPa} \cdot \mathrm{s}$ at $\left.20{ }^{\circ} \mathrm{C}\right) . \tau_{1}$ and $\eta_{2 \mathrm{~Pa}}$ were similar for all emulsions prepared with high pressure but slightly higher than the coarse emulsion. These results are consistent with the occurrence of lower mean diameters (Barnes, 1994). The particle-size effect in the rheology is particularly important for fine dispersions with droplets considerably smaller than $1 \mu \mathrm{m}$ (Pal, 1996). It should be noted that the fitting parameters of emulsions processed with a high pressure homogenizer showed no significant differences regardless of the homogenization pressure or the number of passes.

Figure 3 shows the shear stress at $1 \mathrm{~s}^{-1}$ and flow index values as a function of aging time for the emulsion processed by microfluidization at $15000 \mathrm{psi}$ and one pass, by way of example. All the emulsions exhibited a progressive increase of $\tau_{1}$ and a decrease of $n$ with the aging time. These results point to the development of a more viscous and shear-thinning structure at the top of the sample container (region 


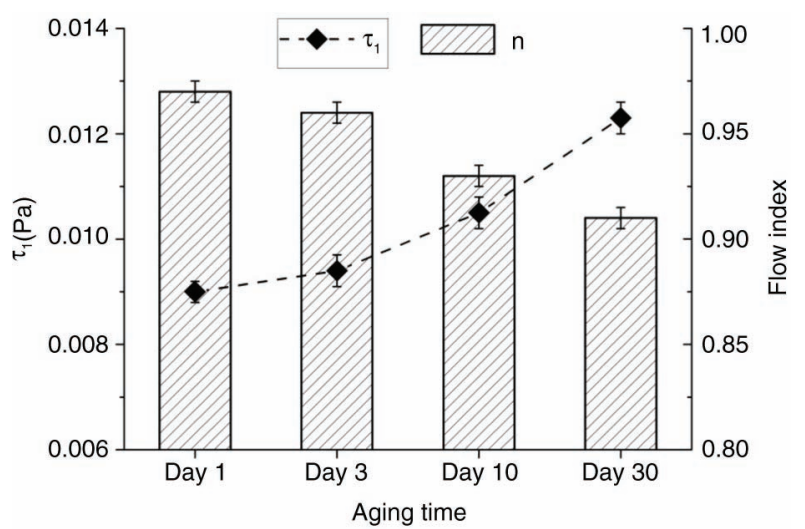

Figure 3. Shear stress values at $1 \mathrm{~s}^{-1}$ and flow index for the emulsion prepared with Microfluidizer M110P at $15000 \mathrm{psi}$ and 1 pass as a function of aging time.

where the sample is taken before being placed on the sensor system prior to measurement), which is likely due to a destabilization process by incipient creaming (Santos et al., 2014). As such, the incipient creaming of these emulsions led to a coalescence phenomenon.

\subsection{Multiple light scattering}

Figures $4 \mathrm{a}$ and $4 \mathrm{~b}$ show back scattering (BS) profiles obtained as a function of time for the emulsions prepared with a) Ultraturrax T50 and b) Microfluidizer M110P at 15000 psi and 1pass, by way of example. These figures also include an inset where BS is plotted at the bottom part of the tube with time in the reference mode (delta-back scattering) to obtain a higher resolution of backs cattering changes. Both emulsions exhibited an increase in the size of the serum layer that displays a decrease in BS at the bottom part of the measurement cell. This result indicates the occurrence of a migration of droplets to the upper part of the cell due to a difference in density between the organic and aqueous phases, i.e., a slight clarification due to an incipient creaming in this zone of the measurement cell (García et al., 2014; Mengual et al., 1999; Santos et al., 2013). Furthermore, the clear decrease in back scattering at the top of the tube (higher decrease for coarse emulsion than for the one prepared by high pressure) indicates a further destabilization process by coalescence, which is less significant than the creaming phenomenon.

The extent of creaming can be characterized by using the creaming index (CI) (McClements, 2007):

$C I=\frac{H_{S}}{H_{E}} \cdot 100$

where $H_{E}$ is the total height of the emulsion and $H_{S}$ is the height of the serum layer.
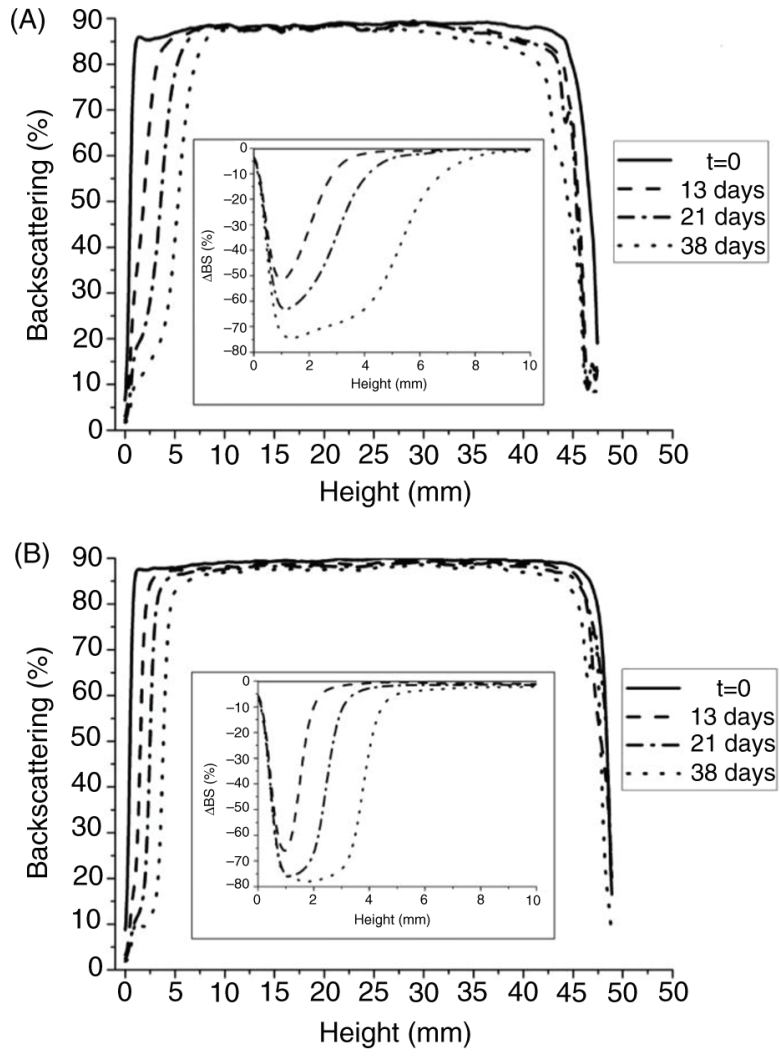

FIGURE 4. Changes in Back scattering profiles as a function of the tube height with the storage time in quiescent conditions for (A) the coarse emulsion and (B) the emulsion prepared with Microfluidizer M110P at 15000 psi and 1 pass. Insets illustrate delta back scattering values at the bottom of the measuring cell. Tube length: $55 \mathrm{~mm}$, temperature: $20^{\circ} \mathrm{C}$.

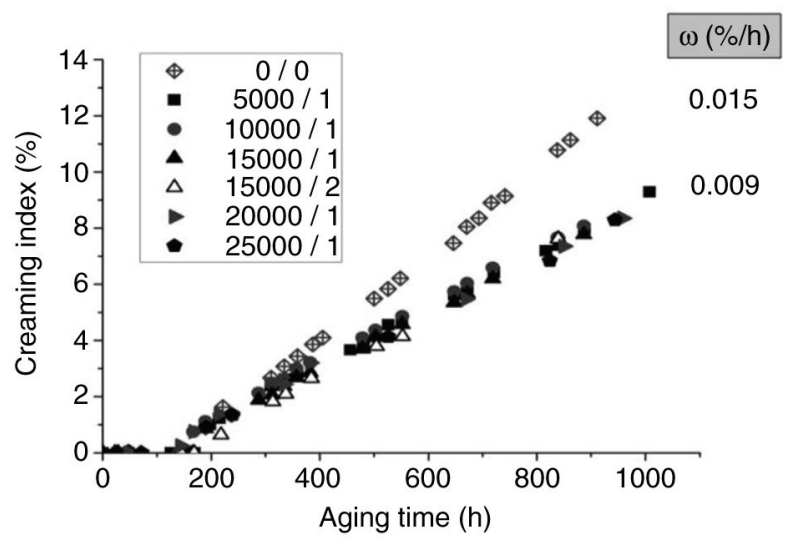

Figure 5. Creaming index (CI) as a function of aging time for selected emulsions. Samples kept under storage at $20^{\circ} \mathrm{C}$.

In Figure 5, the creaming index (CI) is plotted as a function of aging time for all emulsions. Obviously, the value of the creaming index will depend on the time that the measurement is made. Normally, the creaming index should start at zero and increase 
over time as the emulsion droplets move upwards until a fairly constant value $\left(\mathrm{CI}_{\text {final }}\right)$ is reached when all the droplets are packed tightly into the cream layer. The initial slope of the plot of CI versus time $(\mathrm{d}(\mathrm{CI}) / \mathrm{d}(\mathrm{t}))$ is related to the creaming velocity:

$\omega=\frac{d(C I)}{d t} \cdot \frac{H_{E}}{100}$

It was found that the creaming velocity was very similar for all systems prepared with the high-pressure homogenizer. However, an important change in this parameter was found for the coarse emulsion, which exhibited the highest value. This is consistent with the previous results since the creaming rate is influenced by the droplet size and the viscosity of emulsions. Thus, an emulsion with low viscosity and high mean diameters will be more unstable against creaming (McClements, 2007).

Figure 6 illustrates the aspect of the emulsions shown in Figure 4 (coarse emulsion (0/0) and the emulsion prepared by high-pressure homogenization at 15000 psi and 1 pass $(15000 / 1)$ ) after an aging time of 40 days. It is important to note that destabilization by coalescence could only be observed by the naked eye for the emulsion prepared with the rotorstator device (upper part of the measuring cell). By contrast, destabilization by creaming could be visually observed for all emulsions.

\section{CONCLUSIONS}

Regardless of the emulsification method used, the use of a mixture of green solvents and a polyoxyethylene glycerol fatty acid ester derived from cocoa oil as emulsifier led to the creation of emulsions with submicron mean droplet diameters. The high pressure homogenizer achieved a higher fraction of smaller droplets. However, all emulsions prepared

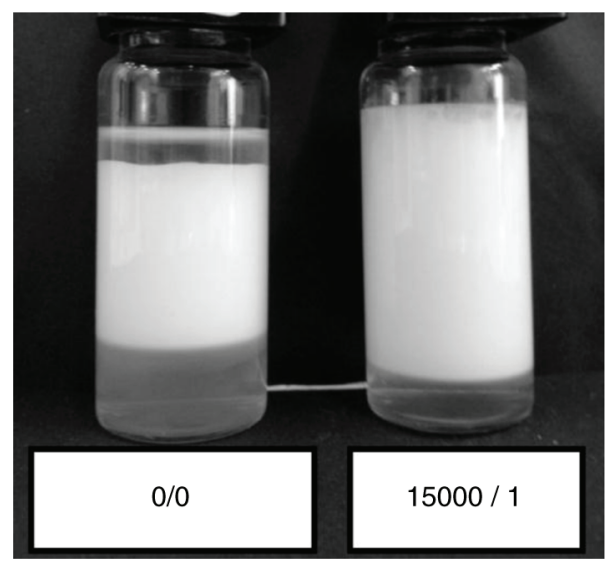

FIGURE 6. Photographs of the coarse emulsion and the emulsion prepared with Microfluidizer M110P at 15000 psi and 1 pass aged for 40 days. by microfluidization showed bimodal distributions. The occurrence of a second peak has been related with a re-coalescence phenomenon induced by an excess of mechanical energy during the emulsifying process. After a short time, the influence of the homogenization pressure on the droplet size distribution of emulsions was not significant, but a second pass through the Microfluidizer led to a slight increase in the mean diameters and span. The ageing time also slightly increases the mean diameters, particularly the volume mean diameter, related to a coalescence process. This process was more significant for the coarse emulsion.

Flow curves of all emulsions exhibited almost Newtonian behavior. The emulsions obtained with the high pressure homogenizer showed higher apparent viscosity and lower flow index values than the coarse emulsion. This result is in agreement with lower mean diameters.

The Multiple light scattering technique allowed for the detection of creaming destabilization and a further coalescence process, which was more significant for the emulsion obtained with the rotor stator homogenizer. The processing variables (pressure and number of passes) did not influence the physical stability of emulsions.

The most stable emulsion was the one prepared with the high-pressure homogenizer at $15000 \mathrm{psi}$ and 1 pass.

\section{ACKNOWLEDGMENTS}

The financial support received (Project CTQ201127371) from the Spanish Ministerio de Economía y Competitividad and from the European Commission (FEDER Programme) is kindly acknowledged. The authors are also grateful to BASF and KAO for providing materials for this research.

\section{REFERENCES}

Barnes HA. 1994. Rheology of emulsions-a review. Colloids Surf. A: Physicochem. Eng. Aspects 91, 89-95. http://dx.doi.org/ 10.1016/0927-7757(93)02719-U.

Bermejo MJ, Castan P, Siscart N, Vilaret J. 2002. Una nueva generación de tensioactivos no-iónicos completamente inocuos, para nuevos desarrollos en detergencia. Comun. Jorn. Com. Esp. Deter. 32, 85-94

Bertouche S, Tomao V, Hellal A, Boutekedjiret C, Chemat F. 2013. First approach on edible oil determination in oilseeds products using alpha-pinene. J. Essent. Oil Res. 25, 439-443. http://dx.doi.org/10.1080/10412905.2013.782473.

Castán P, González X. 2003. Skin properties of glycerine polyethoxylene esters. Comun. Jorn. Com. Esp. Deter. 33, 325-338.

Denolle Y, Seita V, Delaire V. Use of a mixture of alkyl ester of fatty acid of castor oil and at least one ethoxylated glyceride as a cleaning agent. Patent no. 2011/0928 2368971 A1.

Floury J, Legrand J, Desrumaux A. 2004. Analysis of a new type of high pressure homogenizer. Part B. Study of droplet break-up and recoalescence phenomena. Chem. Eng. Sci. 59, 1285-1294. http://dx.doi.org/10.1016/j.ces. 2003.11.025

García MC, Alfaro MC, Calero N, Muñoz J. 2014. Influence of polysaccharides on the rheology and stabilization of 
$\alpha$-pinene emulsions. Carbohyd. Polym. 105, 177-183. http:// dx.doi.org/10.1016/j.carbpol.2014.01.055.

Gómez Herrera C. 2009. Importancia actual de la oleoquímica en el sector industrial de tensioactivos. Grasas Aceites 60, 413-419. http://dx.doi.org/10.3989/gya.032309.

Höfer R, Bigorra J. 2007. Green chemistry. A sustainable solution for industrial specialties applications. Green. Chem. 9, 203-212. http://dx.doi.org/10.1039/b606377b.

Hollinger MA. 2005. Introduction to Pharmacology, Third Edition, CRC Press, United States.

Israelachvili J. 1994. The science and applications of emulsionsan overview. Colloids Surf. A: Physicochem. Eng. Aspects 91, 1-8. http://dx.doi.org/10.1016/0927-7757(94)02743-9.

Jafari SM, He Y, Bhandari B. 2007a. Optimization of nanoemulsions production by microfluidization. Eur. Food Res. Technol. 225, 733-741. http://dx.doi.org/10.1007/s00217006-0476-9.

Jafari SM, He Y, Bhandari B. 2007b. Production of sub-micron emulsions by ultrasound and microfluidization techniques. $J$. Food. Eng. 82, 478-488. http://dx.doi.org/10.1016/j.jfoodeng. 2007.03.007.

Lee JM, Lim KH. 2003. Electroconductometric determination of completely engulfing Maxwell type three phase emulsions. $J$. Ind. Eng. Chem. 9, 248-253.

Lutz PJ. A cleaning composition with multifunctional enhancements systems for personal care, household, and wood products. Patent no. 2006/0822 2537554 A1.

McClements DJ. 2007. Critical review of techniques and methodologies for characterization of emulsion stability. Cri. Rev. Food Sci. 47, 611-649. http://dx.doi.org/10.1080/ 10408390701289292 .

Mengual O, Meunier G, Cayré I, Puech K, Snabre P. 1999. TURBISCAN MA 2000: Multiple Light scattering measurement for concentrated emulsion and suspension instability analysis. Talanta 50, 445-456. http://dx.doi.org/10.1016/ S0039-9140(99)00129-0.

Muñoz J, Alfaro MC, Zapata I. 2007. Avances en la formulación de emulsiones. Grasas Aceites 58, 64-73.

Pal P. 1996. Effect of droplet size on the rheology of emulsions. AICHE J. 92, 3181-3190. http://dx.doi.org/10.1002/aic. 690421119

Pérez-Mosqueda LM, Ramírez P, Trujillo-Cayado LA, Santos J, Muñoz J. 2014. Development of eco-friendly submicron emulsions stabilized by a bio-derived gum. Colloid Surf. B-Biointerfaces 123, 797-802. http://dx.doi.org/10.1016/j. colsurfb.2014.10.022

Ruiz-Márquez D, Partal P, Gómez F, Franco JM, Gallegos C. 2010. Emulsiones alimentarias aceite-en-agua estabilizadas con proteínas de atún. Grasas Aceites 61, 352-360. http:// dx.doi.org/10.3989/gya.112309.

Salvia-Trujillo L, Rojas-Graü MA, Soliva-Fortuny R, MartínBelloso O. 2014. Impact of microfluidization or ultrasound processing on the antimicrobial activity against Escherichia coli of lemongrass oil-loaded nanoemulsions. Food Control 37, 292-297. http://dx.doi.org/10.1016/j.foodcont.2013. 09.015 .

Santos J, Trujillo LA, Calero N, Alfaro MC, Munoz J, 2013. Physical Characterization of a Commercial Suspoemulsion as a Reference for the Development of Suspoemulsions. Chem. Eng. Technol.36, 1883-1890.http://dx.doi.org/10.1002/ ceat. 201300284

Santos J, Trujillo-Cayado LA, Calero N, Muñoz J. 2014. Physical characterization of eco-friendly $\mathrm{O} / \mathrm{W}$ emulsions developed through a strategy based on product engineering principles. AICHE J. 60, 2644-2653. http://dx.doi.org/10.1002/ aic. 14460 .

Schultz S, Wagner G, Urban K, Ulrich J. 2004. High-Pressure Homogenization as a Process for Emulsion Formation. Chem. Eng. Technol. 27, 361-368. http://dx.doi.org/10.1002/ ceat.200406111.

Tadros TF. 2009. Rheology of Dispersions. Principles and Applications. Wiley-VCH, Weinheim, Germany.

Trujillo-Cayado LA, Ramírez P, Pérez-Mosqueda LM, Alfaro MC, Muñoz J. 2013. Perspectives in Fundamental and Applied Rheology, 1, 265-270.

Trujillo-Cayado LA, Ramírez P, Pérez-Mosqueda LM, Alfaro MC, Muñoz J. 2014a. Surface and foaming properties of polyoxyethylene glycerol ester surfactants. Colloids Surf. A: Physicochem. Eng. Aspects 458, 195-202. http://dx.doi. org/10.1016/j.colsurfa.2014.02.009.

Trujillo-Cayado LA, Ramírez P, Alfaro MC, Ruíz M, Muñoz J. 2014b. Adsorption at the biocompatible $\alpha$-pinene-water interface and emulsifying properties of two eco-friendly surfactants. Colloid Surf. B: Biointerfaces 122, 623-629. http://dx.doi.org/10.1016/j.colsurfb.2014.07.041.

Vladisavljević GT, Lambrich U, Nakajima M, Schubert H. 2004. Production of O/W emulsions using SPG membranes, ceramic $\alpha$-aluminium oxide membranes, microfluidizer and a silicon microchannel plate-a comparative study. Colloids Surf. A: Physicochem. Eng. Aspects 232, 199-207. http://dx.doi.org/10.1016/j.colsurfa.2003.10.026.

Yu Y, Zhao J, Bayly AE. 2008. Development of surfactants and builders in detergent formulations. Chinese J. Chem. Eng. 16, 517-527. http://dx.doi.org/10.1016/S1004-9541 (08)60115-9. 